\title{
After Abdication: America Debates the Future of Global Leadership
}

\author{
Peter Marcus Kristensen ${ }^{1}$
}

Received: 31 August 2017/Accepted: 7 September 2017/Published online: 12 September 2017

(C) Fudan University and Springer Nature Singapore Pte Ltd. 2017

\begin{abstract}
American observers of international affairs are currently enmeshed in a debate on the future of global order and leadership. For at least a decade, it has been debated whether the global center of power and leadership is gradually shifting away from the 'declining' West towards 'rising' powers like the BRICS and what consequences this may have for global order, governance and leadership. This paper examines this ongoing debate on the future of global leadership among American observers of international affairs. It finds two main changes in this discourse. First, with the election of President Trump and Brexit-and the resulting uncertainties over the future of NATO, the EU, free trade and climate agreements - there is now a more urgent sense that we are not only witnessing the rise of new powers but the decline of the so-called 'liberal international order' installed after World War II. Second, and most remarkably, the order is collapsing by way of abdication rather than a hegemonic clash between rising and declining powers. Third, and as a consequence, the discourse on a global leadership vacuum, turmoil and world disorder is gaining prominence. The paper argues that diagnoses of the coming of a 'leaderless' or 'G-Zero' world are never only neutral observations of world politics, but also political moves. As such, the narrative of a leadership vacuum can be deployed politically to, variously, call for multilateral engagement, global governance, stronger unilateral leadership, containing aspiring leaders and so on. Moreover, the various diagnoses and prescriptions for a leadership vacuum embody more or less explicit notions of what (good) leadership is and it sees 'the world to be lead' from a distinct perspective. By examining these contemporary debates on global leadership among American intellectuals and policymakers, it sheds light on the broader politics of 'declinism' and a 'leaderless world'.
\end{abstract}

Peter Marcus Kristensen

pmk@ifs.ku.dk

1 Department of Political Science, University of Copenhagen, Øster Farimagsgade 5a, 1353 Copenhagen K, Denmark 
Keywords Liberal international order - United States · Abdication · China · Leadership

\section{After Abdication: The Discourse on a Leaderless World}

A sense that world politics has entered a stage of chaos, disorder and lack of global leadership is currently on the rise among American observers of international affairs. Whether this new era is dubbed a new "world disorder", "no one's world", "non-polar" or "G-Zero" world (Haass 2008; Bremmer and Roubini 2011; Bremmer 2012; Kupchan 2013; Haass 2014; Wolf 2017), the diagnoses is that we are entering an era with no one superpower or hegemon in charge of solving the world's problems and as a result world politics risks becoming much less stable and rules-based, multilateralism and global governance will be significantly weakened, political and economic liberalization will come to a halt, and the world be less a much less safe place than in the 'American century'. The sense of change is so profound that many do not only see current events as the long-predicted end of the "unipolar moment" and the "coming of anarchy" (Mearsheimer 1990; Krauthammer 1991; Kaplan 1994) as the long-awaited "rise of the rest" finally ushers in a "post-American world" (Khanna 2008; Mahbubani 2008; Zakaria 2008; Jacques 2012). These analyses of the consequences of a post-American and leaderless world $^{1}$ have been floating around American foreign policy commentator for years, even decades. They have gained an unprecedented prominence in the recent year or so, however, and, as will be elaborated below, the debate has taken a different shape this time around.

The consensus in American foreign policy circles now appears to be that this is not simply the end of the 'unipolar' post-Cold War era but a much more fundamental break with the post-World War II international order: the decline of the so-called 'liberal international order' installed, maintained and led by the United States in the wake of World War II. Instead, we are entering a period where great powers turn inwards and are neither willing nor able to bear the burdens of global leadership. Even more important in shaping the sense of urgency and novelty, this change is driven by a voluntary abdication of global leadership, under the Trump presidency, rather than a hegemonic clash between rising and declining powers.

As a growing number of observers point to an ongoing break with the post-WWII international order, it has also become increasingly popular to draw analogies from the period that preceded it - the interwar period-to today's turmoil and disorder. Analogies to the 1930s are deployed in numerous ways-economic crisis, the descent into trade wars and blocs, rising populism, nationalism and fascism, the

\footnotetext{
${ }^{1}$ Ever since the World Economic Forum started its Survey on the Global Agenda, lack of global leadership has climbed up the list of pressing global challenges. Already in the Outlook on 2015 survey, $86 \%$ of respondents agreed that there is a leadership crisis in the world. Lack of global leadership was thus identified as the third most pressing issue after deepening income inequality and jobless growth, up from 6th in the 2013 survey (World Economic Forum 2014). Given recent events, one cannot imagine that the outlook on global leadership in 2017 would look more optimistic.
} 
undermining of democratic institutions, the rise of revisionist great powers, and notably the decline of the leading 'status quo' power and its inability, or in the contemporary case, unwillingness to provide global leadership and public goods. The latter-the potential decline of the United States from its superpower statusplays a significant role in the current American discourse on the future global leadership. As the following illustrates, the debate on power transitions, the future of global order and leadership is often a debate on America's decline, the future of the American-led liberal international order and American leadership and soft power.

This paper is not interested in determining whether the United States is really in decline and whether there is in fact a global leadership vacuum, or not, but rather in studying the contours of this debate and its political effects. It does so by examining how American observers of international affairs have debated the question of global leadership over the recent year. I argue that diagnoses of the coming of a 'leaderless' or 'G-Zero' world are never only neutral observations of world politics, but also political moves. The discourse on a leadership vacuum can be deployed politically to do different things, such as to call for stronger unilateral leadership, containing others' attempts to lead or for more multilateral engagement and global governance to mention but a few. Moreover, it embodies more or less explicit notions of what (good) leadership is and it sees the world to be lead from a distinct perspective. By examining the contemporary debate on global leadership among American intellectuals and policymakers, the paper aims to shed light on the broader politics of 'declinism' and a 'leaderless world'.

Methodologically, the paper does so by studying the debate on the future of global leadership in the ten largest US newspapers USA Today, The Wall Street Journal, The New York Times, Los Angeles Times, New York Post, Newsday, Chicago Tribune, New York Daily News, The Washington Post and The Denver Post, as well as the influential policy magazine Foreign Affairs. These sources are selected to get an insight into the American mainstream (dare one say 'establishment'?) discourse on global leadership. The initial search, therefore, focused on articles using the term 'leadership vacuum', 'global leadership' or 'global leader(s)' in Lexis Nexis. The search is also limited to items published in recent years (January 1, 2016 to June 2017). As will be clear below, this is not an argument that the debate on American decline and lack of global leadership is novel, but simply to trace the most recent shape of this otherwise longstanding discourse (and not least how contemporary observers argue that 'this time is real').

\section{The Decline of America and its Liberal Order: An International Relations Classic}

The anxiety about America's decline, and its consequences for global order, governance, institutions, security, and prosperity has always had a special place in the discipline of International Relations. The debate on American decline has a long history-indeed, it can be traced all the way back to the United States' rise to global supremacy_but it has resurfaced with particular force with the conjunction of the 
economic crisis and the rise of new great powers. The literature on American decline, rising powers and the future of the liberal order feeds into a long history of anxiety over potential challengers to American hegemony (USSR, Japan and now China) and an even longer one about the decline of the Western civilization (Spengler 1926; Anderson et al. 2008). There have been waves of declinism ever since America rose to world power (Cox 2007, 2012). 'Optimists' or 'denialists' of various hues have likened declinists to boys prematurely crying wolf (Joffe 2009; Slaughter 2009; Nye 2010, 2011, 2012; Beckley 2011; Drezner 2012; Kagan 2012; Lieber 2012; Wohlforth 2012; Brooks and Wohlforth 2016). 'Declinists' admitted the déjà vu but maintained that the wolf eventually came in that story (Zakaria 2008; Bell 2010; Rachman 2010; Berman 2011; Etzioni 2011; Friedman and Mandelbaum 2011; Rachman 2011; Brzezinski 2012; Cohen 2012; Layne 2012). This spilled over into a debate about the best strategies for the United States to pursue to prolong its dominance in an era of decline: global engagement or retrenchment and off-shore balancing (Brooks et al. 2013; Posen 2013; Kagan 2014; Brands and Feaver 2016; Mearsheimer and Walt 2016).

Through all this, 'revisionist' rising great powers such as the BRICS were seen as the main threat to the so-called 'liberal order' designed and defended by a declining United States - a collective designation used, sometimes quite loosely, to refer to the formal and informal institutions that have produced unprecedented economic growth through free and open trade, produced security through the formation of security alliances and communities, that operates through multilateralism, international law and rules-based interactions, and has promoted democracy and human rights. The concern with rising powers, and their dissatisfaction in particular, has been underpinned by power transition theory claiming that major power war are more likely when there is (1) a power parity between established and rising power, (2) when there is high differential growth and the transition, therefore, is taking place in a fast pace, (3) particularly if the rising power has already overtaken the established power and (4) when the rising power is dissatisfied with the status quo order and rules installed by the established power (Organski 1968; Organski and Kugler 1980; Tammen et al. 2000). This has led to a wealth of studies, published over the past decade or so, of the power differential between the United States and especially China, the potential sources of rising power dissatisfaction and revisionism, potential power transition scenarios and policies for handling them (Johnston 2003; Chan 2005; Tammen 2006; Tammen and Kugler 2006; Goldstein 2007; Legro 2007; Levy 2008; Feng 2009; Kastner and Saunders 2012; Rapkin and Thompson 2013; Chen and Pu 2014; Brooks and Wohlforth 2016).

The preoccupation with the rising powers as the main challenge to America's leadership role, and the liberal international order itself, characterized the state of debate until very recently. Indeed, some of the very earliest articles surveyed for this paper, published before the election of Donald Trump, still write into the established debate about America's global (dis)engagement and the danger rising revisionist powers pose to the liberal international order (e.g. Daalder and Kagan 2016; Kaplan 2016; Lieberman 2016). Yet, a quite sudden shift in the American discourse on global order and leadership can be identified in the latter part of the period surveyed 
here. Now, it seems the main challenge to the liberal international order comes from within.

\section{This Time is Different: From Hegemonic Contest to Abdication}

A good indication that something has changed is when the author of the liberal victory march, 'The End of History', argues that “Today, the greatest challenge to liberal democracy comes not so much from overtly authoritarian powers such as China, as from within" (Fukuyama 2016). Much of this stems from a concern over rising domestic authoritarianism as expressed in attacks on free media, undermining the rule of law, judiciaries and permanent bureaucracies, threats to imprison opponents, the encouragement of violence and racism, praise for dictators, and so on (Mickey et al. 2017). However, in relation to global leadership and order, the topic of this special issue, the main change concerns the shift from focusing on external threats to US leadership and the liberal international order towards the threats from within. China and Russia pose challenges to liberalism "but the more important threats to the order are internal", argues Niblett (2017), as the EU is undergoing a process of disintegration and the "U.S. commitment to global leadership, which until now has sustained the order through good times and bad, looks weaker than at any point since World War II". While the European part of the equation-rising populism, nationalism, xenophobia and disintegration-was seen as a challenge in the post-Brexit, pre-election period, it was not seen as a grave threat to the future liberal order and global leadership itself (see the 2016 Foreign Affairs issue on populism, for example). Post-election, however, observers overwhelmingly point to how America itself may be undermining and even voluntarily abdicating its historic leadership role in the liberal international order: The argument in mainstream foreign policy outlets is that Trump has voluntarily abdicated America's traditional leadership role by questioning its long-standing alliances, multilateral ones such as NATO and bilateral ones in Asia, or at least taking a transactional approach to them, by withdrawing from free trade arrangements, new ones such as the TPP and renegotiating old ones such as NAFTA, and even threatening a trade war, by tearing up the Paris climate accords as well as a the Iran nuclear deal, by replacing a tolerant and multicultural attitude to difference with a jingoistic and nationalist one, and generally by replacing a grand strategy of global engagement where America held the mantle of global leadership with an isolationist 'America first' doctrine focused on national gain. In the words of the president himself "I'm not, and I don't want to be, the president of the world" (Washington Post 2017).

This change is evident from recent issues Foreign Affairs, arguably the preeminent foreign policy magazine in the United States. In issues titled "Present at the destruction" and "Out of Order", previous defenders of the liberal order, such as Robert Keohane and John Ikenberry, emphasize how the rise of populism in the wake of the economic crisis means that the UK and US have turned their back on multilateralism and international 'engagement' more broadly (Colgan and Keohane 2017; Ikenberry 2017; Nye 2017). Ikenberry exemplifies the astonishment over the 
fact that the prevailing order would come under pressure from within rather than the outside:

"Is the world witnessing the demise of the U.S.-led liberal order? If so, this is not how it was supposed to happen. The great threats were supposed to come from hostile revisionist powers seeking to overturn the postwar order. The United States and Europe were supposed to stand shoulder to shoulder to protect the gains reaped from 70 years of cooperation. Instead, the world's most powerful state has begun to sabotage the order it created. A hostile revisionist power has indeed arrived on the scene, but it sits in the Oval Office, the beating heart of the free world" (Ikenberry 2017: 2).

Global orders come and go, Ikenberry notes, but what is new-and surprising - is that such order most often end in "murder" of their sponsors rather than in hegemonic "suicide" (Ikenberry 2017: 2). Contrary to academic expectations, as well as those prevailing in the wider foreign policy community, Trump has "abdicated" responsibility for leading the world "America made" (Ikenberry 2017: 3). "America's postwar global leadership", Susan Rice, the former National Security Advisor, argues "was not taken from us by any adversary, nor lost as a result of economic crisis or collapse of empire. America voluntarily gave up that leadership_-because we quit the field". Even Graham Allison, who popularized the idea of a Thucydides' Trap in which a rising China and declining United States would inevitably clash over global leadership recently argued that "we are absenting the field" (cited in Sanger and Perlez 2017). Or as Ratner (2017) argues within a regional context, "U.S. regional leadership [in Asia] is much more likely to go out with a whimper than with a bang". What is interesting about the shift in the diagnosis is also the policy prescriptions it opens up. As the diagnosis shifts from the main threat to the United States' global position being great power war between competing hegemons as envisioned by the "Thucydides' Trap" to hegemonic suicide, the prescriptions also becomes less about caution, restraint, de-escalation and reassurance that aims integrate and 'satisfy' rising powers than about 'daring to act', deter and reassert America's historic leadership-and often contain Chinese leadership in the process (Ratner 2017).

\section{The Dangers of a Leadership Vacuum: From Thucydides' to Kindleberger's Trap}

This signals somewhat of a departure in the academic literature on global order and leadership: The greatest danger in contemporary international affairs is, therefore, not the power transition between the US and China in itself, but that this transition and other forces have left us in a situation with 'no one in charge': a global "leadership deficit" (Lehmann 2016). America's abdication and the resulting lack of global public goods provision, Nye (2017) argues, "is why the most important challenge to the provision of world order in the twenty-first century comes not from without but from within". He, therefore, argues that we should not fear a 'Thucydides Trap' as much as a 'Kindleberger Trap': namely, that we should not 
only be concerned about an inevitable clash between United States and China (such as Britain and Germany around the World Wars), with the latter challenging the order installed by the former, as a product of the power transition. Rather, we should fear a situation where the inability of the existing great power (Britain then, the United States today) to support the order it had built results in a leadership vacuum that produces disasters like in the 1930s. According to this logic, consistent with Kindleberger's hegemonic stability theory, the rules and norms of a given order are not self-enforcing but need a state hegemon to support - and preferably abide bythem (Mazarr 2017).

Leadership, in this view, is defined as system stewardship: the sacrifice of shortterm national interest for the greater sake of maintaining the status quo order, rules and institutions; the provision of public goods that benefit all, not just the steward. The United States was seen as a leader when it "stood for more than just its own well-being and that the world economy was not a zero-sum game" (Patrick 2017). "Leadership is not the same as domination", as Nye (2017) emphasizes. Other observers of international relations have also emphasized the lack of global leadership along similar lines of the 'Kindleberger Trap'. Bremmer (2015) of the Eurasia Group, for example, has long been arguing that "the world lacks leadership" and that "a G-zero world is now fully upon us". In his view "the biggest structural risk is the lack of global governance" and that this is only produced in part by the United States. A "G-Zero world" is not equivalent to, or produced solely by, America's decline: "American capacity and willingness to provide global leadership certainly is much less than it was. Perhaps more importantly, no one else individually and no constellation of powers are prepared to step up and fill even a portion of that role, and so what we have is an absence of global leadership, and this is what I've been talking about: the G-zero" (Grundleger and Creehan 2012).

The fear of weak American leadership, if not its complete abdication from global leadership, also has a history. Critics of President Obama, for example, see a longstanding US leadership vacuum dating at least to his administration. Particularly, its red line and subsequent decision not to intervene in Syria is seen as a "lack of public global leadership" (Kristof 2016). Critics of Obama have, therefore, long argued that "the world has never seemed as dangerous and leaderless as it does now" and that "The absence of American leadership has certainly not caused all the instability, but it has encouraged and exacerbated it" (Lieberman 2016). Obama's "Leading from behind" and "lack of leadership" in the Middle East is similarly criticized for allowing other powers such as Russia and Iran to fill the vacuum (Thornberry and Krepinevich 2016). By contrast, Trump's immediate response to a gas attack was seen as a potential step to "fill the leadership vacuum" (Washington Post 2017). Some even go so far as to argue that Trump does not signal the end of US leadership but rather a "disruptive change" that will "revitalize" the "crumbling international order" and "world in disarray" left behind by the Obama administration (Kroenig 2017). The particular case of the Syria strike is often singled out as an example of "American moral leadership" because it was not undertaken for direct national gain (except perhaps to impress president $\mathrm{Xi}$ ) but served to enforce norms on weapons of mass destruction on behalf of the 
international community (Abrams 2017; Haass 2017). Nevertheless, it is quite telling of the way global leadership is conceived, by some observers, that Trump is seen as most presidential and taking on the traditional mantle of global leadership only when he sent 59 cruise missiles into Syria-while having dinner with $\mathrm{Xi}$ Jinping. Global leadership is conceived as taking action, not necessarily to solve global problems but to at least "do something". The power vacuum is used in this regard to justify engagement and intervention, unilateral if necessary. ${ }^{2}$

The idea of a power void or vacuum, which pervades many of the articles surveyed here, is an interesting but often unquestioned spatial metaphor. The basic idea is that the international consists of void spaces that must be filled by someone. As the United States abdicates, it leaves behind completely empty spaces around the world. Assuming that no one else already occupied this space, the expectation is that someone will enter to fill the vacuum.

\section{Vacuums Tend to Fill: Containing Aspiring Leaders}

What is interesting is not only the different diagnoses of the problem of a leadership 'vacuum' or 'void', but how it is used to put forward certain political solutions as a response. Here, two tendencies are striking: the mainstream US discourse on the coming 'leadership vacuum' is not primarily about the global governance problems left unsolved as the US abdicates its leadership role (i.e. climate change, civil wars, trade barriers, laggard economic growth, rising authoritarianism, terrorism and so on) but rather about the damage it does to US power, influence, credibility and image around the world and the fact that other great powers might take over its historic leadership role.

One of the most common questions asked following the 'leadership vacuum' diagnosis is who will step into the void left by the United States. Prior to the election of Trump, this rhetorical figure could take the shape of countering China by taking on economic leadership in the Asia-Pacific or Russia and Iran's exploitation of a geopolitical leadership vacuum in Eastern Europe and the Middle East by having the United States "reassert its historic leadership role" because "today's morass is in part the consequence of a leadership vacuum" (Kasich 2016; Lieberman 2016; Washington Post 2016b). Post-Trump when the likelihood of a US reasserting its global leadership role seems diminished, defenders of the liberal order still point to the dangers of China, Russia and Iran filling the vacuum. Warning that an isolationist 'America First', may in fact result in putting 'China First' as the global leader. In that sense, the discourse on the decline of American and the liberal order is still very intertwined with that on the rise of China.

\footnotetext{
${ }^{2}$ This is not limited to the US discourse. For instance, one can also find calls for Britain to fill the vacuum in the Middle East. "There is a global leadership vacuum which the UK can and must step into fill—even more urgently following the referendum, to counter any idea of our "strategic shrinkage" from the world". And "Down the ages, Britain has been a beacon for liberal values and humanitarianism. In these desperate times, the lives of terrorised people of Aleppo depend on international leaders finding the courage to act" (Mitchell 2016).
} 
Much of the discourse surrounding potential global leaders filling the "void" and "exploit the leadership vacuum" after the American abdication concentrates on China (Sanger and Perlez 2017; Zakaria 2017). Xi Jinping's speech at the World Economic Forum in Davos-whose theme was "responsive and responsible leadership"-features in most sources as a central turning point in asserting China's commitment to free trade, economic cooperation, stewardship, and a global leadership role after the US abdication (Ehrenfreund 2017; Nakamura 2017; Wong 2017b). Trade and investment initiatives like the One Belt, One Road project, the Asian Infrastructure Investment Bank, the New Development Bank and Regional Comprehensive Economic Partnership are also frequently mentioned as indications of China's assertion of global, or at least regional, leadership, particularly after the US withdrawal from the Trans-Pacific Partnership (Tweed and Olorunnipa 2016; Fidler 2017; Perlez and Buckley 2017). In terms of economic leadership in Asia, in particular, Trump's withdrawal from the TPP is viewed as a "big win" for China that "created a void that President Xi was already practicing to fill" (Perlez and Buckley 2017) and allowed China to roll out a "more audacious version of the Marshall Plan" (Perlez and Huang 2017). Chinese and European alignment on trade and climate change is also covered with some alarm, arguing for instance that "America's traditional allies are on the lookout for new friends... [and that] Many are looking to China, which adroitly capitalized on a leadership vacuum" (Goodman 2017).

Ikenberry (2017: 4) also laments the fact that China "has already begun to step into the geopolitical vacuum Trump is creating". Pointing to the Davos speech in terms of economic leadership, the defense of free trade and investment, this is somewhat paradoxical considering that Ikenberry foresaw this outcome: that rising powers would see that they benefit from an open, rules-based order and thus overtake it when they become more powerful than the Western powers that installed it (Ikenberry 2008). More in line with Ikenberry's original arguments, others have argued that China "understands and appreciates the order more than is commonly realized" (Nye 2017). Others, in turn, have been more skeptical that China will be capable, and even willing, to bear the burdens of global leadership and to provide global public goods, at least beyond the economic sphere where it benefits China's own national interest in economic growth and national rejuvenation ( $\mathrm{Hu}$ and Spence 2017). And not in stopping ISIS, stabilizing the Middle East, mitigating climate change, containing the proliferation of weapons of mass destruction, and so on (Bremmer 2015). Regardless, Chinese leadership is rarely welcomed in the elite US discourse.

Particularly, President Trump's announcement in early June 2017 that the US will withdraw from the Paris climate accord has been widely viewed as creating "a vacuum of global leadership that presents ripe opportunities to allies and adversaries alike to reorder the world's power structure...the greatest strategic gift to the Chinese, who are eager to fill the void that Washington is leaving around the world" (Sanger and Perlez 2017). The withdrawal was widely interpreted as an "abdication" that "ceded" global leadership to China and an important opportunity for China to boost its soft power, even if there is also some questioning whether China is willing to take on the role as a global leader in fighting climate change 
(Deese 2017; Kaiman and Zavis 2017; Krupp 2017; Morello and Wagner 2017; Shao 2017; Wong 2017a). Retreat from leadership on climate change is seen as particularly damaging because it is high consensus issue supported by a broad coalition of states, including US allies which reaffirmed their commitment immediately afterwards, thus damaging US "soft power", credibility and ability to build coalitions on other issues (Deese 2017; Morello and Wagner 2017). Conversely when it comes to Chinese leadership, the fear is not that China will take responsibility on climate change per se, but that in so doing it will exploit the tensions between the United States and Europe to forge new partnerships, if not alliances (Sanger and Perlez 2017). Richard Haass of the Council of Foreign Relations, arguing that Trump has "certainly made the world safe for Chinese influence" (Sanger and Perlez 2017). Trump "has wreaked havoc", Rice (2017) argued, "hobbling our core alliances, jettisoning American values and abdicating United States leadership of the world. That's a whole lot of winning-for Russia and China".

\section{Liberal Leadership and American Exceptionalism}

Key to understanding the resistance to Chinese global leadership among US foreign policy commentators is that the current leadership vacuum is often conceived as a liberal leadership vacuum. One element of liberal leadership has to do with stewardship over the instititions, rules and norms of the liberal international order. China could in principle take leadership over some of these institutions, however, so the notion of liberal leadership runs deeper than that. It also implies liberalism conceived as global leaders that are politically liberal, democratic, respect human rights and the rule of law. In which case China falls short: "The leader of an open system must itself be open" (Kausikan 2017). This definition of leadership ties into the American exceptionalist discourse of being not just a leader, but "Leader of the Free World" (Applebaum 2016; Kasich 2016).

Several other observers stress the exceptionalism of America's leadership role, arguing that "The idea of America has been at the heart of our success in the world for 70 years. For all our imperfections, we have embodied political and economic openness, respect for human dignity and a sense of possibility" (Burns 2017). The "power of our example" and commitment to "what is best in us" means that "no country is better positioned than the United States to lead in the twenty-first century", argues Joe Biden, as he warns against turning inwards (Biden 2016). Arguments based on American exceptionalism tend to follow a particular logic in which only America can lead in this particular manner, thus portraying a world without American leadership as a disaster for the entire globe. This type of analysis lends itself mostly to a political call for reinvigorating American ideas, values, soft power and diplomacy - the solution is more America: "At a moment when the international order is under severe strain, power is fragmenting and great-power rivalry has returned, the values and purpose at the core of the American idea matter more than ever" (Burns 2017). Without American leadership, as a Washington Post editorial puts it, the "world would become a much colder-and more dangerous- 
place" (Washington Post 2016a). The solution, John Kasich argues another piece, is to "send a message to the world that we are the global leader, today and forever" (Kasich 2016). Global leadership, in this conception, is not only about solving global problems in, say, trade or climate change, but it is equally important who solves these problems and how. America is "indispensable" (Kausikan 2017).

The call for liberal, and not just any kind of, leadership does lead some to put their faith in Japan and Germany to "step up" as the only credible liberal alternatives (Ikenberry 2017:3) and in some cases Canada under Trudeau and France under Macron (New York Times 2017). As "Trump is abdicating all moral power", according to this line of argument, "The world has no choice but to move on" (Robinson 2017). Angela Merkel's beer hall speech after the G-7 meeting in May 2017 calling for Europeans to take their fate in their own hands and not rely completely on others in doing so is also read as a step in this direction. Overall, however, it is remarkable how few US foreign policy commentators put their faith in European allies to provide global leadership. Many are pessimistic about Europe's ability, not willingness, to be a global leader (Bremmer 2015).

Finally, it is quite striking how few commentators use the 'leadership vacuum' diagnosis to encourage more global governance, a strengthening of multilateral, institutionalized and collective leadership. Global leadership is mainly conceived in state- and US-centric terms. Some scholars do use of the decline and leadership vacuum narrative to call for reform of the liberal order, however. That is, a call to reform the declining order to preserve, adapt and renovate it, as opposed to tearing it down (Haass 2017). Proposals for reform take two main forms. One concerns the (liberal) values and norms underpinning the order and the other concerns its inclusivity and stewards. As for the former, some suggest reforming the liberal order by making it benefit more people so as to defuse populist sentiments ( $\mathrm{Hu}$ and Spence 2017). To defenders of the liberal order everyone loses if the order erodes [or more people stand to lose than win (Ikenberry 2017:8)], but they also acknowledge that the order has benefitted the few. To put it in Ruggie's famous term, it has lost its embeddedness and is now mostly (neo)liberal. ${ }^{3}$ So there are some calls from reform, a 'derigging' of liberal order, primarily by softening its economic liberalism, to benefit people more broadly (Colgan and Keohane 2017). As for the latter, a few observers suggest global governance reform in the sense of giving rising powers a greater stake. In this view, one of the main threats to the liberal order, apart from rising populism and nationalism in the West, is that rising powers like the BRICS have greater ambitions but feel disenfranchised by the order. The proposal here is to build a more diverse and inclusive order by making "accommodations to enfranchise non-Western powers while upholding the essential rules of an open trading system" (Mazarr 2017; see also Feigenbaum 2017). Reform by inclusion remains a minority view, however, especially after the election of President Trump.

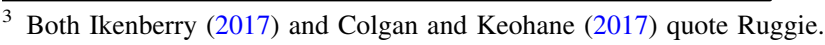




\section{Conclusion}

The future of America's global leadership and the so-called American-led liberal order has become the most central question to American foreign policy commentators after the election of President Trump. This paper has examined this American discourse on global leadership to shed light on the politics of 'declinism' and a 'leaderless world'. It founds that the foreign policy establishment is struggling, in particular, with the fact that America seems to be abdicating this role voluntarily. Only some years ago, few would suggest that the challenge to the liberal international order would come from home. Instead, most of the attention was directed towards rising revisionist powers and the threat they posed to the liberal order. Although America's own abdication is seen as a major source of instability and disorder, this paper nonetheless finds a corollary anxiety is about the threat of China 'stepping into void'. The narrative of a leadership vacuum is most deployed to call for stronger unilateral leadership and containing aspiring leaders while voices calling for more multilateral engagement and reform of global governance are few and far between. The paper examined only the outlets associated with the foreign policy establishment and rather than a debate proper it found an almost consensus anxiety about the future of the liberal international order and America's role in it. While Trump and Trumpism might turn out to be an aberration, it is worth noting that the American foreign policy establishment seems more disconnected from the kitchens of power than ever. While the theory-policy gap in American IR has long been lamented (George 1993; Nye 2008; Jentleson and Ratner 2011), the current disconnect has a much more fundamental character. And perhaps critical scholars also need to revise the notion of the power-knowledge nexus and the 'revolving door' that has long been used to characterize American IR (Hoffmann 1977; Smith 2002).

This paper has looked only at the American side of the story, it is worth noting that the Chinese foreign policy establishment is also experiencing a debate over whether China should assume more global leadership and how. Traditionally reluctant to present itself as a global leader, and especially one that overtakes leadership from the United States, China's intellectuals and policymakers have nevertheless started debating their country's potential leadership role after America's abdication [particularly after Xi Jinping's Davos Speech, see (Chen 2017)]. While there is not space to go into Chinese debates on global leadership here-a topic that is also touched upon by other contributions to this special issueit is not unlikely that a study of how Chinese foreign policy commentators and policymakers approach to the current 'leadership deficit' would have many resemblances to that of the United States. The discourse on a leadership vacuum and world disorder can also be deployed to call for Chinese leadership. To argue that Chinese leadership is, by definition, better, more benevolent, humane and moral leadership (Yan 2011a, b, 2016). That in a disorderly world, more China would be a source of order and harmony (Zhao 2009). That China is an exceptional country (Callahan 2012; Zhang 2013). In contrast to the American debate, however, Chinese leaders have only shown willingness to lead in selective areas, not to impose and 
uphold a comprehensive global order. The discourse on Chinese leadership is, therefore, likely to focus more on global governance issues of immediate benefit to China and its economic and social development (trade, investment, climate and the environment) but not on others (Syria, terrorism, civil war). The real test for Chinese leadership will be when the world expects China to 'do something' about children being gassed or journalist being decapitated on Youtube. Even China may then be regretting America's abdication.

Acknowledgements Funding was provided by Samfund og Erhverv, Det Frie Forskningsråd (Grant no. 5052-00046B).

\section{References}

Abrams, Elliott. 2017. Trump the Traditionalist. Foreign Affairs 96: 10-16.

Anderson, Jeffrey J., G. John Ikenberry, and Thomas Risse (eds.). 2008. The End of the West?: Crisis and Change in the Atlantic Order, 1st ed. Ithaca: Cornell University Press.

Applebaum, Anne. 2016. Is America Still the Leader of the Free World? The Washington Post. https:// www.washingtonpost.com/opinions/global-opinions/under-president-trump-america-may-nolonger-lead-the-free-world/2016/11/09/921bbbbe-a67b-11e6-ba59-a7d93165c6d4_story.html?utm_ term=.db56f50c5e32. Accessed 8 June 2017.

Beckley, Michael. 2011. China's Century? Why America's Edge Will Endure. International Security 36: 41-78.

Bell, David A. 2010. Political Columnists Think America Is In Decline. Big Surprise. The New Republic October 27. http://www.tnr.com/blog/foreign-policy/78216/america-in-decline-thomas-friedman.

Berman, Morris. 2011. Why America Failed: The Roots of Imperial Decline. Hoboken, NJ: Wiley.

Biden Jr., Joseph R. 2016. Building on Success. Foreign Affairs 95: 46-57.

Brands, Hal, and Peter Feaver. 2016. Should America Retrench? Foreign Affairs 95: 164-169.

Bremmer, Ian. 2015. Absence of Global Leadership Will Shape a Tumultuous 2016. http://time.com/ 4154044/geopolitics-2016/. Accessed 2 June 2017.

Bremmer, Ian. 2012. Every Nation for Itself: Winners and Losers in a G-Zero World. New York: Portfolio.

Bremmer, Ian, and Nouriel Roubini. 2011. A G-Zero World. Foreign Affairs 90: 2-7.

Brooks, Stephen and William Wohlforth. 2016. The Once and Future Superpower. Why China Won't Overtake the United States. Foreign Affairs 95: 91-104.

Brooks, Stephen G., G. John Ikenberry, and William C. Wohlforth. 2013. Lean Forward: Defense of American Engagement. Foreign Affairs 92: 130.

Brzezinski, Zbigniew. 2012. Strategic Vision: America and the Crisis of Global Power. New York: Basic Books.

Burns, William J. 2017. The Risks of the Trump Administration Hollowing out American Leadership. The Washington Post. https://www.washingtonpost.com/opinions/dont-be-fooled-trump-is-stillhollowing-out-american-leadership/2017/04/19/d2b64e02-2450-11e7-b503-9d616bd5a305_story. html?utm_term=.f66364b4a2c5. Accessed 6 June 2017.

Callahan, William A. 2012. Sino-Speak: Chinese Exceptionalism and the Politics of History. The Journal of Asian Studies 71: 33-55.

Chan, Steve. 2005. Is There a Power Transition between the U.S. and China? The Different Faces of National Power. Asian Survey 45: 687-701.

Chen, Dingding. 2017 Is China Ready for Global Leadership? The Diplomat. http://thediplomat.com/ 2017/02/is-china-ready-for-global-leadership/. Accessed 8 June 2017.

Chen, Dingding, and Xiaoyu Pu. 2014. Primacy or World Order? The United States and China's Rise-A Review Essay. International Security 38: 176-180.

Cohen, Michael A. 2012. Rotting From the Inside Out. Foreign Policy. http://www.foreignpolicy.com/ articles/2012/02/21/rotting_from_the_inside_out. Accessed 11 Sept 2017.

Colgan, Jeff D., and Robert O. Keohane. 2017. The Liberal Order Is Rigged: Fix It Now or Watch It Wither. Foreign Affairs 96: 36. 
Cox, Michael. 2007. Is the United States in Decline-again? An Essay. International Affairs 83: 643-653.

Cox, Michael. 2012. Power Shifts, Economic Change and the Decline of the West? International Relations 26: 369-388.

Daalder, Ivo, and Robert Kagan. 2016. The U.S. Can't Afford to End Its Global Leadership Role. The Washington Post. https://www.washingtonpost.com/opinions/the-us-cant-afford-to-end-its-globalleadership-role/2016/04/22/da297be0-062a-11e6-b283-e79d81c63c1b_story.html?utm_term=.5cc8 c605ad61. Accessed 7 June 2017.

Deese, Brian. 2017. Paris Isn't Burning. Foreign Affairs 96: 83-92.

Drezner, Daniel W. 2012 Predictions about the Death of American Hegemony May Have Been Greatly Exaggerated. Foreign Policy. http://drezner.foreignpolicy.com/posts/2012/01/22/predictions_about_ the_death_of_american_hegemony_may_have_been_greatly_exaggerated. Accessed 22 February 2012.

Ehrenfreund, Max. 2017. Proponents at World Economic Forum Meet to Ensure Globalism Isn't Done yet. Washington Post. http://www.chicagotribune.com/business/ct-world-economic-forumglobalism-20170118-story.html. Accessed 7 June 2017.

Etzioni, Amitai. 2011. Lessons of America's "Decline". International Journal of Contemporary Sociology 48: 173-188.

Feigenbaum, Evan A. 2017. China and the World. Foreign Affairs 96: 33-40.

Feng, Huiyun. 2009. Is China a Revisionist Power? The Chinese Journal of International Politics 2 : 313-334.

Fidler, Stephen. 2017. China's Xi Jinping Speech Seen as Move to Fill Global Leadership Role. Wall Street Journal. http://www.wsj.com/articles/chinas-xi-jinping-speech-seen-as-move-to-fill-globalleadership-role-1484660546. Accessed 2 June 2017.

Friedman, Thomas L., and Michael Mandelbaum. 2011. That Used to Be Us: How America Fell Behind in the World It Invented and How We Can Come Back. New York City: Farrar, Straus and Giroux.

Fukuyama, Francis. 2016. US against the world? Trump's America and the new global order. The Financial Times, 11 November 2016. https://www.ft.com/content/6a43cf54-a75d-11e6-8b6902899e8bd9d1. Accessed 11 Sept 2017.

George, Alexander L. 1993. Bridging the Gap: Theory and Practice in Foreign Policy. Washington: United States Institute of Peace Press.

Goldstein, Avery. 2007. Power Transitions, Institutions, and China's Rise in East Asia: Theoretical Expectations and Evidence. The Journal of Strategic Studies 30: 639-682.

Goodman, Peter S. 2017. U.S. Allies Gird for a Trade War. The New York Times. https://www.nytimes. com/2017/01/30/business/economy/trumps-mexico-china-tariff-trade.html. Accessed 8 June 2017.

Grundleger, Joshua, and Sean Creehan. 2012. The Global Leadership Vacuum: An Interview with Ian Bremmer, President and Founder, Eurasia Group. SAIS Review of International Affairs 32: 5-17.

Haass, Richard N. 2008. The Age of Nonpolarity. Foreign Affairs 87: 44-56.

Haass, Richard N. 2014. The Era of Disorder. Project Syndicate. http://www.project-syndicate.org/ commentary/new-era-of-global-instability-by-richard-n-haass-2014-10. Accessed 29 Jan 2015.

Haass, Richard N. 2017. Where to Go From Here (Cover Story). Foreign Affairs 96: 2-9.

Hoffmann, Stanley. 1977. An American Social Science: International Relations. Daedalus 106: 41-60.

Hu, Fred, and Michael Spence. 2017. Why Globalization Stalled. Foreign Affairs 96: 54-63.

Ikenberry, G.John. 2017. The Plot against American Foreign Policy: Can the Liberal Order Survive. Foreign Affairs 96: 2.

Ikenberry, John. 2008. The Rise of China and the Future of the West; Can the Liberal System Survive? Foreign Affairs 87: 23.

Jacques, Martin. 2012. When China Rules the World: The End of the Western World and the Birth of a New Global Order: Second Edition. New York: Penguin Books. (Revised edition).

Jentleson, Bruce W., and Ely Ratner. 2011. Bridging the Beltway-Ivory Tower Gap. International Studies Review 13: 6-11.

Joffe, Josef. 2009. The Default Power: The False Prophecy of America's Decline. Foreign Affairs 88: $21-35$

Johnston, Alastair Iain. 2003. Is China a Status Quo Power? International Security 27: 5-56.

Kagan, Robert. 2012. Not Fade Away: The Myth of American Decline. The New Republic 243: 19-25.

Kagan, Robert. 2014. Superpowers Don't Get to Retire. New Republic. https://newrepublic.com/article/ 117859/superpowers-dont-get-retire. Accessed 2 June 2017. 
Kaiman, Jonathan, and Alexandra Zavis. 2017. The U.S. Is Abdicating Its Role as the World's Climate Leader. Can China Take Its Place? Los Angeles Times. http://www.latimes.com/world/asia/la-fgchina-climate-20170405-story.html. Accessed 8 June 2017.

Kaplan, Robert D. 2016. Eurasia's Coming Anarchy. Foreign Affairs 95: 33-41.

Kaplan, Robert D. 1994. The Coming Anarchy. The Atlantic. https://www.theatlantic.com/magazine/ archive/1994/02/the-coming-anarchy/304670/. Accessed 6 June 2017.

Kasich, John R. 2016. A Treaty to Preserve U.S. Leadership. The Washington Post. https://www. washingtonpost.com/opinions/john-kasich-refusing-to-ratify-tpp-risks-americas-role-as-the-worldleader/2016/10/12/a8f8d6fe-9092-11e6-9c52-0b10449e33c4_story.html?utm_term=.53160c62b450. Accessed 7 June 2017.

Kastner, Scott L., and Phillip C. Saunders. 2012. Is China a Status Quo or Revisionist State? Leadership Travel as an Empirical Indicator of Foreign Policy Priorities. International Studies Quarterly 56: $163-177$.

Kausikan, Bilahari. 2017. Asia in the Trump Era. Foreign Affairs 96: 146-153.

Khanna, Parag. 2008. The Second World: Empires and Influence in the New Global Order. London: Allen Lane.

Krauthammer, Charles. 1991. The Unipolar Moment. Foreign Affairs 70: 23-33.

Kristof, Nicholas. 2016. Obama's Worst Mistake. The New York Times: 23. https:/www.nytimes.com/ 2016/08/11/opinion/obamas-worst-mistake.html?mcubz=1. Accessed 6 June 2017.

Kroenig, Matthew. 2017. The Case for Trump's Foreign Policy. Foreign Affairs 96: 30-34.

Krupp, Fred. 2017. Trump and the Environment. Foreign Affairs 96: 73-82.

Kupchan, Charles A. 2013. No One's World: The West, the Rising Rest, and the Coming Global Turn, Reprint ed. New York: Oxford University Press.

Layne, Christopher. 2012. This Time It's Real: The End of Unipolarity and the Pax Americana. International Studies Quarterly 56: 203-213.

Legro, Jeffrey W. 2007. What China Will Want: The Future Intentions of a Rising Power. Perspectives on Politics 5: 515-534.

Lehmann, Jean-Pierre. 2016. Donald Trump and the Contemporary Leadership Deficit. Forbes. https:// www.forbes.com/sites/jplehmann/2016/05/07/donald-trump-and-the-contemporary-leadershipdeficit/\#77f23889294a. Accessed 2 June 2017.

Levy, Jack. 2008. Power Transition Theory and the Rise of China. In China's Ascent: Power, Security, and the Future of International Politics, ed. Robert S. Ross, and Feng Zhu. Ithaca: Cornell University Press.

Lieber, Robert J. 2012. Power and Willpower in the American Future: Why the United States Is Not Destined to Decline, 1st ed. Cambridge: Cambridge University Press.

Lieberman, Joseph I. 2016. The Absence of U.S. Leadership Makes the World More Dangerous than Ever. https://www.washingtonpost.com/opinions/the-absence-of-us-leadership-makes-the-worldmore-dangerous-than-ever/2016/02/24/65e586a8-d8ac-11e5-925f-1d10062cc82d_story.html?utm_ term=.20149f69ace7. Accessed 17 May 2017.

Mahbubani, Kishore. 2008. The New Asian Hemisphere: The Irresistible Shift of Global Power to the East. New York: PublicAffairs.

Mazarr, Michael J. 2017. The Once and Future Order. Foreign Affairs 96: 25-32.

Mearsheimer, John. 1990. Back to the Future: Instability in Europe after the Cold War. International Security 15: 5 .

Mearsheimer, John J., and Stephen M. Walt. 2016. The Case for Offshore Balancing: A Superior US Grand Stategy. Foreign Affairs. 95: 70.

Mickey, Robert, Steven Levitsky, and Lucan Ahmad Way. 2017. Is America Still Safe for Democracy? Foreign Affairs 96: 20-29.

Mitchell, Andrew. 2016. Britain Needs to Fill the Global Leadership Vacuum That Is Allowing Bashar Al-Assad to Starve Syrians. The Telegraph. http://www.telegraph.co.uk/news/2016/08/02/britainneeds-to-fill-the-global-leadership-vacuum-that-is-allow/. Accessed 2 June 2017.

Morello, Carol, and John Wagner. 2017. Experts See Shift in Global Leadership in U.S. Withdrawal. Washington Post. https://www.washingtonpost.com/world/national-security/as-the-us-leaves-parisclimate-accord-some-see-shifts-in-global-leadership/2017/06/01/4c916554-4634-11e7-a196a1bb629f64cb_story.html?utm_term=.38253a1661dc. Accessed 5 June 2017.

Nakamura, David. 2017. As Trump Pursues 'America First,' China's Xi Sees Opening for Primacy in Asia. Washington Post. https://www.washingtonpost.com/politics/as-trump-pursues-america-first- 
chinas-xi-sees-opening-for-primacy-in-asia/2017/04/04/c8b9b570-1937-11e7-855e-4824bbb5d748_ story.html. Accessed 8 June 2017.

New York Times. 2017. Mr. Macron's Striking International Debut. The New York Times. https://www. nytimes.com/2017/06/01/opinion/emmanuel-macron-putin-versailles.html?mcubz=1. Accessed 8 June 2017.

Niblett, Robin. 2017. Liberalism in Retreat. Foreign Affairs 96: 17-24.

Nye, Joseph S. 2008. Bridging the Gap between Theory and Policy. Political Psychology 29: 593-603.

Nye, Joseph S. 2010. The Future of American Power. Foreign Affairs 89: 2-12.

Nye, Joseph S. 2011. The Future of Power. New York: PublicAffairs.

Nye, Joseph S. 2012. The Twenty-First Century Will Not Be a "Post-American" World. International Studies Quarterly 56: 215-217.

Jr, Nye, and S. Joseph. 2017. Will the Liberal Order Survive: The History of an Idea. Foreign Affairs 96: 10.

Organski, A.F.K. 1968. World Politics. New York City: Knopf.

Organski, A.F.K., and Jacek Kugler. 1980. The War Ledger. Chicago: University Of Chicago Press.

Patrick, Stewart M. 2017. Trump and World Order. Foreign Affairs 96: 52-57.

Perlez, Jane, and Chris Buckley. 2017. Injecting Risk in China Ties. The New York Times: 1. Perlez, Jane, and Chris Buckley. 2017 Trump Injects High Risk in Relations with China. The New York Times: 1. https://www.nytimes.com/2017/01/24/world/asia/trump-us-china-trade-trans-pacific-partnership. html. Accessed 6 June 2017.

Perlez, Jane, and Yufan Huang. 2017. Remaking Global Trade in China's Image. The New York Times: 6. http://www.nytimes.com/images/2017/05/14/nytfrontpage/scannat.pdf?mcubz=1. Accessed 8 June 2017.

Posen, Barry R. 2013. Pull Back: The Case for a Less Activist Foreign Policy. Foreign Affairs 92: 116-128.

Rachman, Gideon. 2011 American Decline: This Time It's for Real. Foreign Policy 184: 59-65.

Rachman, Gideon. 2010. Zero-Sum World. Financial Times.

Rapkin, David P., and William R. Thompson. 2013. Transition Scenarios: China and the United States in the Twenty-First Century. Chicago: University of Chicago Press.

Ratner, Ely. 2017. Course Correction. Foreign Affairs 96: 64-72.

Rice, Susan. 2017. To Be Great, America Must Be Good. The New York Times: 21. https://www.nytimes. com/2017/06/02/opinion/trump-america-leadership-susan-rice.html. Accessed 6 June 2017.

Robinson, Eugene. 2017. Trump Is Abdicating All the Country's Moral Power. The Washington Post. https://www.washingtonpost.com/opinions/trump-is-abdicating-all-the-countrys-moral-power/2017/ 06/01/709ad08a-4705-11e7-98cd-af64b4fe2dfc_story.html?utm_term=.0f4ccec20fa2. Accessed 8 June 2017.

Sanger, David E., and Jane Perlez. 2017 Trump Hands the Chinese a Gift: The Chance for Global Leadership. The New York Times. https://www.nytimes.com/2017/06/01/us/politics/climate-accordtrump-china-global-leadership.html. Accessed 6 June 2017.

Shao, Wanyun. 2017. Trump's Decision to Withdraw from the Paris Accord Cedes Global Leadership to China. The Conversation. http://theconversation.com/trumps-decision-to-withdraw-from-the-parisaccord-cedes-global-leadership-to-china-76279. Accessed 2 June 2017.

Slaughter, Anne-Marie. 2009. America's Edge-Power in the Networked Century. Foreign Affairs 88: 94.

Smith, Steve. 2002. The United States and the Discipline of International Relations: "Hegemonic Country, Hegemonic Discipline”. International Studies Review 4: 67-86.

Spengler, Oswald. 1926. The Decline of the West [1918]. Trans. Charles Francis Atkinson. AA Knopf, New York City.

Tammen, Ronald, and Jacek Kugler. 2006. Power Transition and China-US Conflicts. Chinese Journal of International Politics 1: 35-55.

Tammen, Ronald, Jacek Kugler, Douglas Lemke, Allan C. Stam, Mark Abdollahian, Carole Alsharabati, Brian Efird, and A.F.K. Organski. 2000. Power Transitions-Strategies for the 21st Century. New York: Sage.

Tammen, Ronald L. 2006. The Impact of Asia on World Politics: China and India Options for the United States1. International Studies Review 8: 563-580.

Thornberry, Mac, and Andrew F. Krepinevich Jr. 2016. Preserving Primacy. Foreign Affairs 95: 26-35. 
Tweed, David, and Toluse Olorunnipa. 2016. China Moves to Fill World Leadership Void as Trump Era Dawns. Bloomberg.com. https://www.bloomberg.com/politics/articles/2016-11-20/china-flips-roleswith-u-s-in-trump-era-with-rebukes-on-policy. Accessed 2 June 2017.

Washington Post. 2016a. The End the U.S. Global Leadership. https://www.washingtonpost.com/ opinions/global-opinions/a-president-trump-could-end-the-era-of-american-global-leadership/2016/ 10/03/75776ed2-8677-11e6-92c2-14b64f3d453f_story.html?utm_term=.7bc5138f0f1d. Accessed 7 June 2017.

Washington Post. 2016b. The Liberal International Order Is under Fire. The United States Must Defend It; Combat Russia and China's Affronts to Democracy, Accountability and Human Dignity. Washington Post.

Washington Post. 2017. Trump's Chance to Step into the Global Leadership Vacuum; The Military Action in Syria Creates an Opportunity. How Will the President Follow Up? Washington Post. http://www.lexisnexis.com.ep.fjernadgang.kb.dk/lnacui2api/api/version1/getDocCui?lni=5N89FWR1-JB4M-V2S2\&csi=8075\&hl=t\&hv=t\&hnsd=f\&hns=t\&hgn=t\&oc=00240\&perma $=$ true. Accessed 2 June 2017.

Wohlforth, William C. 2012. How Not to Evaluate Theories. International Studies Quarterly 56: 219-222.

Wolf, Martin. 2017. The Long and Painful Journey to World Disorder. Financial Times. https://www.ft. com/content/ef13e61a-ccec-11e6-b8ce-b9c03770f8b1. Accessed 8 June 2017.

Wong, Edward. 2017a. Can China Take the Lead on Climate Change? That Could Be Difficult. The New York Times. https://www.nytimes.com/2017/06/02/climate/china-climate-change-trump-parisaccord.html?mcubz=1. Accessed 8 June 2017.

Wong, Edward. 2017b. As China Seeks Bigger Role on World Stage, Xi Jinping Will Go to Davos World Economic Forum. The New York Times: 6. https://www.nytimes.com/2017/01/10/world/asia/davoschina-xi-jinping-trump.html?mcubz=1. Accessed 8 June 2017.

World Economic Forum. 2014. Outlook on the Global Agenda 2015. World Economic Forum. https:// www.weforum.org/reports/outlook-global-agenda-2015. Accessed 2 June 2017.

Yan, Xuetong. 2011a. How China Can Defeat America. http://www.nytimes.com/2011/11/21/opinion/ how-china-can-defeat-america.html. Accessed 21 Feb 2012.

Yan, Xuetong. 2011b. International Leadership and Norm Evolution. The Chinese Journal of International Politics 4: 233-264.

Yan, Xuetong. 2016. Political Leadership and Power Redistribution. The Chinese Journal of International Politics 9: 1-26.

Zakaria, Fareed. 2008. The Post-American World. New York: W. W. Norton \& Company.

Zakaria, Fareed. 2017. Trump Could Be the Best Thing That Has Happened to China in Long Time. Washington Post.

Zhang, Feng. 2013. The Rise of Chinese Exceptionalism in International Relations. European Journal of International Relations 19: 305-328.

Zhao, Tingyang. 2009. A Political World Philosophy in Terms of All-under-Heaven (Tian-Xia). Diogenes 56: 5-18.

Peter Marcus Kristensen is Associate Professor at the Department of Political Science, University of Copenhagen. His research interests include the sociology of the International Relations discipline, nonWestern perspectives and theories on international relations, and theories on rising powers and peaceful change. 